\title{
ANALISIS PENGARUH DANA ALOKASI UMUM (DAU), PAJAK DAERAH, DAN JUMLAH PENDUDUK TERHADAP PERTUMBUHAN EKONOMI DI PROVINSI NUSA TENGGARA BARAT TAHUN 2011-2017
}

\author{
Filza Andrian Maulana, Dwi Susilowati \\ Program Studi Ekonomi Pembangunan, Fkaultas Eknomi dan Bisnis, Universitas Muhammadiyah \\ Malang, J1.Raya Tlogomas No.246 Malang, Indonesia \\ * Corresponding author: maulanaand5@gmail.com
}

\begin{tabular}{|c|c|}
\hline Artikel Info & Abstract \\
\hline Article history: & This study aims to determine the effect of general \\
\hline Received 25 November 2019 & allocation funds (DAU), local taxes, and population on \\
\hline Revised 5 December 2019 & economic growth in West Nusa Tenggara Province. \\
\hline Accepted 10 January 2020 & Fiscal decentralization is one form of authority that local \\
\hline Available online 15 February & governments have since the enactment of Law no. 22 of \\
\hline 2020 & $\begin{array}{l}\text { 1999. The implementation of fiscal decentralization was } \\
\text { only implemented in Indonesia on January } 1,2001 \text { based }\end{array}$ \\
\hline $\begin{array}{l}\text { Keyword: fiscal } \\
\text { decentralization, economic }\end{array}$ & $\begin{array}{l}\text { on Law no. } 25 \text { of } 1999 \text { concerning the financial balance } \\
\text { between the central government and local governments. }\end{array}$ \\
\hline growth, general allocation $f$ & The variables studied are general allocation funds, \\
\hline local taxes, population & $\begin{array}{l}\text { regional taxes, and total population, the type of data used } \\
\text { is secondary data with the 2011-2017 period. By using }\end{array}$ \\
\hline JEL Classification & panel data analysis method. The results of the analysis \\
\hline E01, H11, H72 & show that the influence between the General Allocation \\
\hline & Fund and Total Population variables on Economic \\
\hline & $\begin{array}{l}\text { Growth is positive and significant, while the regional tax } \\
\text { on economic growth is significant negative. }\end{array}$ \\
\hline
\end{tabular}

\section{PENDAHULUAN}

Desentralisasi fiskal bukanlah merupakan konsep baru yang di terapkan di Indonesia. Dalam penerapan desentralisasi fiskal memiliki tujuan yaitu untuk meningkatkan pertumbuhan ekonomi serta peningkatan pendapatan daerah. Namun dalam kenyataannya pelaksanaan desentralisasi fiskal tersebut mneimbulkan fenomena-fenomena yang banyak terjadi kasus dalam penerapannya, yaitu untuk mencapai dua tujuan tersebut tidak bisa selalu beriringan. Dalam pengalihan otoritas atau kewenangan pengelolaan keuangan daerah dari pemerintah pusat ke pemerintah daerah ternyata tidak dapat diberlakukan di semua wilayah.

Pengelolaan Pemerintah.daerah, baik ditingkat Provinsi maupun ditingkat kabupaten dan kota memasuki era baru dengan dikeluarkannya Undang Undang No.22 Tahun 1999 yang memberlakukan peluang bagi setiap daerah untuk mengelola potensi sumber daya alam yang dimiliki secara efesien dan efektif. Ada tiga faktor yang perlu dilihat dalam menjalankan desentralisasi fiskal, yaitu berkaitan dengan kemandirian pengambilan keputusan yang dilakukan di daerah (Bird and Vaillan-court, 2000:7). Pertama, desentralisasi fiskal berarti adanya pelepasan tanggung jawab yang berada dalam lingkungan Pemerintah Pusat ke Pemerintah daerah secara vertikal. Kedua, delegasi yang berhubungan dengan situasi, yaitu daerah daerah bertugas sebagai perwakilan dari Pemerintah untuk melaksanakan fungsi-fungsi tertentu atas nama Pemerintah Pusat. Ketiga, devolusi 
(pelimpahan) yang berhubungan dengan suatu situasi yang bukan saja implementasi tetapi juga kewenangan untuk memutuskan apa yang perlu dikerjakan, khususnya yang bertempat di daerah.

Perubahan pada Undang-undang No. 22 Tahun 1999 dalam hubungan pemerintah pusat dan daerah, yaitu perubahan sistem pemerintahan dari bentuk sentralistis menjadi desentralistis, artinya bahwa adanya pengalihan sebagian besar wewenang pemerintahan pusat kepada pemerintah daerah. Adapun.wewenang yang tetap menjadi otoritas pemerintah pusat adalah di bidang politik luar negeri, pertahanan dan keamanan, peradilan, moneter, serta agama. Pelaksanaan desentralisasi fiskal di kabupaten/kota Provinsi Nusa Tenggara Barat menunjukkan hasil yang relatif baik meskipun belum optimal. Pemerintah daerah membutuhkan modal untuk meningkatkan pertumbuhan ekonomi, yang diperoleh dari potensi ekonomi daerah serta transfer yang diberikan dari Pemerintah pusat. jika dalam pemenuhan modal Pemerintah daerah hanya mengandalkan transfer dari Pemerintah pusat, maka pertumbuhan ekonomi menjadi terhambat.

Berdasarkan penelitian yang dilakukan oleh Adi (2005) melakukan penelitian dampak desentralisasi fiskal terhadap pertumbuhan ekonomi. Metode yang digunakan adalah metode ekonometrika dengan menggunakan ANOVA. Pelaksanaan desentralisasi fiskal terbukti meningkatkan pertumbuhan ekonomi daerah. Namun hasil yang didapat tidak semua semua daerah siap memasuki desentralisasi fiskal, masih ada 46\% daerah yang belum siap memasuki daerah desentralisasi fiskal. Namun pertumbuhan ekonomi ini tidak diikuti dengan kenaikan pertumbuhan pendapatan perkapita.

Pernyataan Slinko (2002) memepertegas pengertian dari desentralisasi fiskal yaitu sebagai bentuk transfer kewenangan (tanggung.jawab dan fungsi) dari pemerintahpusat kepada pemerintah daerah, termasuk di dalamnya pemberian otoritas bagi pemerintah daerah untuk mengelola penerimaan dan pengeluaran daerahnya sendiri.

Menurut Mahi (2002) pada dasarnya bahwa kajian dalam pelaksanaan desentralisasi fiskal dapat menggunakan dua pendekatan, yaitu pendekatan expenditure assignment dan revenue assigment. Pendekatan expenditure assigment menyatakan bahwa terjadi perubahan tanggung jawab pelayanan publik dari pemerintah pusat ke pemerintah daerah, sehingga menigkatkan peran lokal public goods. Sedangkan dalam pendekatan revenue assignment dijelaskan bahwa peningkatan kemampuan keuangan daerah melalui alih sumber pembiayaan pusat kepada daerah, dalam bentuk membiayai fungsi yang didesentralisasikan.

Dalam laju pertumbuhan ekonomi yang dilihat dari tingkat produk domestik regional bruto (PDRB) atas dasar harga konstan 2010, meningkat trus sepanjang waktu dari 2011 sampai 2017. Dapat dilihat dari gambar di bawah ini : 


\section{Gambar 1. PDRB Atas Dasar Harga BerlakuTahun 2010 Provinsi Nusa Tenggara Barat $2011-2017$}

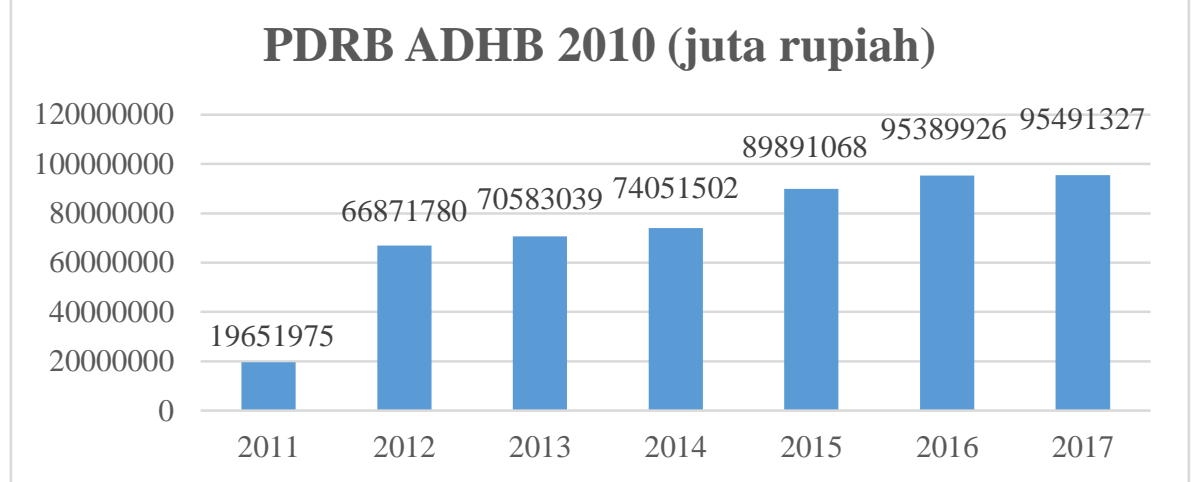

Sumber: BPS Provinsi Nusa Tenggara Barat Dalam Angka, 2017

Dari gambar di atas dapat diketahui bahwa dari tahun 2011 - 2017 tingkat pertumbuhan ekonomi Provinsi Nusa Tenggara Barat terus meningkat pada tahun 2011 sebesar 19.651.975 miliar rupiah dan trus meingkat hingga sebesar 95.491.327 miliar rupiah pada tahun 2017. Hampir disemua daerah di Provinsi Nusa Tenggara Barat perekonomian cenderung meningkat, tetapi pertumbuhan tersebut belum mampu menyerap jumlah pengangguran yang cukup besar di wilayah ini, sehingga diperlukan laju pertumbuhan yang lebih baik lagi untuk mendorong kinerja ekonomi makro daerah.

Terdapat beberapa indikator untuk melihat pertumbuhan ekonomi daerah. Pertama, dilihat dari hasil output pembangunan daerah yang tercermin dalam Produk Domestik Regional Bruto (PDRB). Kedua dilihat dari Pendapatan Asli Daerah (PAD), dalam mencukupi anggaran belanja daerah kemampuan PAD sangat dibutuhkan untuk proses pertumbuhan ekonomi daerah. Menurut (Saragih, 2016) peningkatan PAD sebenarnya merupakan akses dari pertumbuhan ekonomi daerah yang pertumbuhan ekonominya positif mempunyai kemungkinan mendapatkan kenaikan PAD, dari prespektif ini Pemerintah daerah harus lebih berkonsentrasi pada pemberdayaan kekuatan ekonomi lokal untuk menciptakan pertumbuhan ekonomi daripada sekedar mengeluarkan produk perundangan terkait dengan pajak atau retribusi.

Ketiga, dilihat dari banyaknya jumlah penduduk, menurut teori Klasik bahwa output akan berkembang sejalan dengan perkembangan penduduk. Pertumbuhan penduduk yang tinggi tidak diikuti oleh kebijakan Pemerintah yang baik dalam menghadapi masalah ini, maka pertumbuhan penduduk yang tinggi hanya akan membawa dampak yang buruk bagi suatu daerah. Menurut teori Malthus menyatakan bahwa pertumbuhan penduduk menurut deret ukur sementara pertumbuhan bahan makanan menurut deret hitung, bukan kesejahteraan yang didapat tapi justru kemelaratan akan di temui bila mana jumlah penduduk tidak dikendalikan dengan baik. 


\section{Gambar 1. Jumlah Penduduk Provinsi Nusa Tenggara Barat 2011 - 2017}

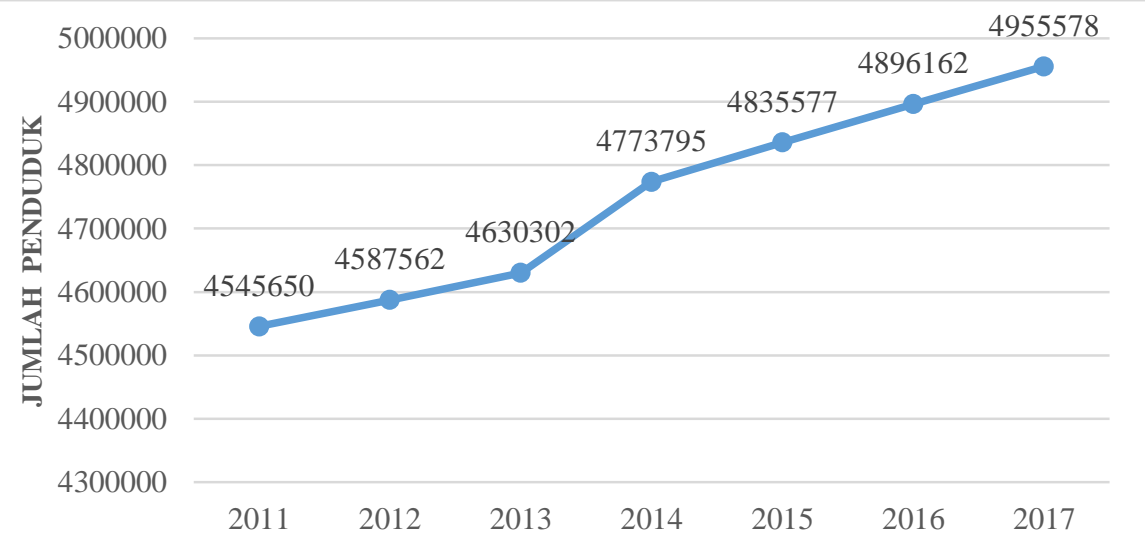

Sumber: BPS Provinsi Nusa Tenggara Barat Dalam Angka, 2017

Dari data di atas dapat di ketahui bahwa jumlah penduduk di Nusa Tenggara Barat setiap tahun mengalami peningkatan. Berdasarkan hasil Proyeksi pada tahun 2017 jumlah penduduk Nusa Tenggara Barat mengalami peningkatan yang cukup signifikan yaitu sebesar adalah 4,9 juta jiwa sedangkan 6 tahun sebelumnya pada tahun 2011 hanya sebesar 4,5 juta jiwa.

Tujuan pengalokasian Dana Alokasi Umum adalah dalam rangka pemerataan kemampuan penyediaan pelayanan public diantara pemerintah daerah di Indonesia. Secara implisit, Dana Alokasi Umum bertujuan untuk menetralkan dampak peningkatan ketimpangan antar daerah sebagai akibat bagi hasil pajak dan SDA yang tidak merata. Dana Alokasi Umum untuk satu wilayah dialokasikan atas dasar celah fiskal (fiscal gap) dan alokasi dasar (Simanjuntak, 2005). Pertumbuhan ekonomi sudah menjadi salah satu target dari setiap negara di Dunia untuk meningkatkan perekonomian negaranya masing-masing. Pertumbuhan ekonomi selalu menjadi faktor yang paling penting dalam keberhasilan perekonomian suatu negara untuk jangka panjang. Pertumbuhan ekonomi sangat dibutuhkan dan dianggap sebagai sumber peningkatan standar hidup (standar of living) penduduk yang jumlahnya terus meningkat setiap tahunnya.

"Economic Development is Growth Plus Change" yang berarti pembangunan ekonomi adalah pertumbuhan ekonomi yang diikuti oleh perubahan-perubahan dalam struktur dan corak (Sukirno, 2008). Simon Kuznets dalam Sukirno, mendefenisikan pertumbuhan ekonomi sebagai suatu bentuk peningkatan bagi suatu negara untuk menyediakan barang-barang ekonomi yang dibutuhksn oleh penduduknya, pertumbuhan kemampuan ini disebabkan oleh kemajuan teknologi, kelembagaan, serta penyesuaian ideologi yang dibutuhkan (Sukirno, 2010).

Dengan di lihat dari tingkat perbedaan yang demikian, dikhawatirkan pelaksanaan desentralisasi fiskal yang pada dasarnya ditujukan untuk memajukan dan mengakselerasi perkembangan dan pertumbuhan ekonomi daerah-daerah, justru akan terjadi sebaliknya yaitu di sisi lain akan terjadi kesejahteraan masyarakat lokal cenderung tidak mengalami perubahan. Akan 
tetapi tidak dapat disangkal juga bahwa pelaksanaan desentralisasi fiskal dapat mempercepat pertumbuhan dan pembangunan di berbagai kabupaten/kota di Provinsi Nusa Tenggara Barat.

\section{METODE PENELITIAN}

Penelitian ini merupakan penelitian Diskriptif Kuantitatif. Penelitian diskriptif kuantitatif digunakan untuk mengukur suatu kosnep variabel yaitu pengaruh variabel bebas (independen) terhadap variabel terikat (dependen) sehingga lebih mudah dipahami secara statistik. Adapun Objek dari penelitian ini adalah Desentralisasi Fiskal, Dana Alokasi Umum, Pajak Daerah dan Jumlah Penduduk dan Pertumbuhan Ekonomi di kabupaten/kota Provinsi Nusa Tenggara Barat.

Dalam penelitian ini, daerah yang akan dijadikan objek penelitian adalah seluruh kabupaten/kota di Provinsi Nusa Tenggara Barat. Menurut pembagian wilayah administrasi Indonesia Provinsi Nusa Tenggara Barat terdiri dari 8 kabupaten dan 2 kota dengan periodesasi waktu dari tahun 2011 sampai 2017.

Variabel-variabel yang digunakan dalam penelitian ini adalah:

a. Variabel dependen (dependent variable), yaitu pertumbuhan ekonomi (PE)

b. Variabel bebasnya (independent variable) antara lain: Dana Alokasi Umum (DAU), Pajak Daerah (PD), dan Jumlah Penduduk.

1. Variabel Dependen (Y)

Pertumbuhan Ekonomi (PE) adalah sebagai variabel dependent atau variabel terikat merupakan variabel yang dipengaruhi atau menjadi akibat oleh variabel independen, berarti perkembangan kegiatan dalam perekonomian yang menyebabkan barang dan jasa yang diproduksikan dalam masyarakat dan kemakmuran masyarakat meningkat. Pertumbuhan ekonomi wilayah diukur melalui logaritma natural Pendapatan Domestik Regional Bruto (PDRB) atas dasar harga konstan (ADHK 2010) menurut kabupaten/Kota di Provinsi Nusa Tenggara Barat selama periode 2011-2017 (dalam satuan rupiah). PDRB merupakan kesulurahan nilai barang atau jasa yang dihasilkan oleh seluruh unit ekonomi disuatu wilayah dalam waktu tertentu. Untuk sumber data diambil dari Badan Pusat Statistik (BPS).

2. Variabel Independen (X)

a.) Dana Alokasi Umum (X1)

Dana Alokasi Umum (DAU) adalah dana yang bersumber dari pendapatan APBN yang dialokasikan untuk pemerataan kemampuan keuangan antar daerah dalam rangka pelaksanaan desentralisasi.

b.) Pajak Daerah (X2)

Pajak Daerah (PD) dalam penelitian ini didekati dengan jumlah total pajak masing-masing kabupaten/kota sebagai persentase terhadap PDRB kabupaten/kota tersebut. Pendekatan ini mengikuti penelitian Jin dan Zou (2000).

c.) Jumlah Penduduk (X3) 
Jumlah Penduduk merupakan semua orang yang berdomisili di wilayah geografis Republik Indonesia selama 6 bulan (lebih atau kurang) dengan tujuan untuk menetap (BPS). Pada penelitian ini indikator jumlah penduduk dapat diketahui dengan banyaknya jumlah penduduk menurut kabupaten/kota di Provinsi Nusa Tenggara Barat selama periode 2011-2017 (dalam jiwa). Sumber data diambil dari Badan Pusat Statistik (BPS) melalui Sensus Penduduk.

Jenis data yang digunakan dalam penelitian ini adalah data sekunder, dimana data tersebut diperoleh berdasarkan informasi yang telah disusun dan dipublikasikan oleh instansi tertentu (Soeratno \& Lincoln, 2003). Dengan metode data panel (pooled data) yaitu gabungan dari data times cross section dan series (Gujarati and Porter, 2012). Data cross section adalah data yang dikumpulkan dalam satu waktu terhadap banyak individu, sedangkan data time series adalah data yang dikumpulkan dari waktu ke waktu terhadap satu individu.

Penelitian ini menggunakan metode analisis regresi linier berganda dengan metode regresi data panel (pooled data) dengan melalui program software Microsoft Excel 2013 dan E-views 2008, yang mana akan dipilih pendekatan yang terbaik dari common effect, fixed effect, random effect dengan cara menggunakan suatu uji regresi data panel yaitu Uji Chow, Uji Haustman, dan Uji Lagrange Multiplier. Penelitian ini untuk mengetahui seberapa besar pengaruh variabel independen yaitu Desentralisasi fiskal terhadap variabel dependen yaitu pertumbuhan ekonomi. Model persamaan sebagai berikut :

$$
P E_{i t}=\mathrm{a}+\beta_{1} D A U_{i t}+\beta_{2} P D_{i t}+\beta_{3} J P D_{i t}+e_{i t}
$$

Keterangan :

$$
\begin{aligned}
& \text { PEit = Pertumbuhan Ekonomi PDRB per kapita kabupaten/kota } \\
& \text { atas dasar harga konstan (jutaan rupiah) } \\
& \text { a } \quad=\text { constanta } \\
& \beta_{1}, \beta_{2}, \beta_{3}, \beta_{4}=\text { Koefisien regresi } \\
& D A U_{i t} \quad=\text { Jumlah Dana Alokasi Umum kabupaten/kota i pada tahun } \mathrm{t} \\
& P D_{i t} \quad=\text { Jumlah Pajak Daerah kabupaten/kota i pada tahun } \mathrm{t} \text { (jutaan } \\
& \text { rupiah) } \\
& J P P_{i t} \quad=\text { Jumlah Penduduk kabupaten/kota i pada tahun } \mathrm{t} \\
& \text { (Jumlah/Jiwa) } \\
& \text { e } \quad=\text { errorterm }
\end{aligned}
$$

\section{Metode Pengujian Hipotesis}

Pengujian hipotesis penelitian dilakukan dengan pendekatan estimasi metode regresi panel dengan menggunakan uji F-statistic yaitu melihat bagaimana pengaruh semua variabel bebas secara bersama-sama terhadap variabel terikatnya, Uji t yaitu dilakukan untuk menguji pengaruh variabel independen sendiri-sendiri terhadap variabel dependen, dan Koefisien 
Determinasi (adjusted) yaitu besarnya derajat kemampuan variabel bebas terhadap variabel terikat dari suatu regresi.

\section{HASIL DAN PEMBAHASAN}

Pemilihan model menggunakan Uji Chow, dan Uji Hausman model yang tepat digunakan yaitu Fixed Effect (tabel 2).

Maka diperoleh regresi sebagai berikut:

$Y_{i t}=52.18689-4.856386 \log X_{1 i t}+0.440372 \log X_{2 i t}-7.816775 \log X_{3 i t}+e_{i t}$

Dari persamaan diatas dapat di interpretasikan sebagai berikut:

Pengaruh Dana Alokasi Umum (DAU)

Berdasarkan hasil analisis regresi linier berganda data panel dengan model fixed effect, variabel dana alokasi umum berpengaruh positif dan signifikan terhadap tingkat pertumbuhan ekonomi. Artinya apabila dana alokasi umum menigkat sebesar $1 \%$ maka akan meningkatkan tingkat pertumbuhan ekonomi sebesar $4.856386 \%$. Hal tersebut menunjukkan bahwa apabila dana alokasi umum mengalami peningkatan maka akan meningkatkan tingkat pertumbuhan ekonomi di Provinsi Nusa Tenggara Barat.

Jika dilihat dari hasil bahwa dana alokasi umum berpengaruh positif dan signifikan terhadap tingkat pertumbuhan ekonomi maka hal ini sesuai dengan pendapat Brata (2004) yang menyatakan bahwa terdapat komponen penerimaan daerah yang berpengaruh positif secara signifikan terhadap pertumbuhan ekonomi regional yaitu PAD. Apabila peningkatan PAD dapat mendorong pertumbuhan ekonomi daerah, maka terdapat kemungkinan dana alokasi umum (DAU) dan dana alokasi khusus (DAK) juga berpengaruh positif terhadap pertumbuhan ekonomi, karena nilai DAU dan DAK pada umumnya lebih besar dibandingkan kontribusi PAD.

Pemerintah Pusat mengeluarkan dana perimbangan berupa dana alokasi umum untuk mengatasi ketimpangan infrastruktur yang ada pada setiap daerah agar terciptanya pertumbuhan ekonomi yang merata. DAU adalah dana yang bersumber dari pendapatan Anggaran Pendapatan Belanja Negara (APBN) yang dialokasikan dengan tujuan pemerataan kemampuan keuangan antar daerah untuk mendanai kebutuhan daerah dalam rangka pelaksanaan desentralisasi (UndangUndang No.33 Tahun 2004). DAU merupakan sumber pendanaan yang penting bagi pemerintah daerah, DAU bisa didistribusikan untuk mengatasi ketimpangan pendapatan antar daerah baik horizontal maupun vertikal (Gan, Wang, Chen, 2005)

\section{Pengaruh Pajak Daaerah}

Berdasarkan hasil analisis regresi linier berganda data panel dengan model fixed effect, variabel pajak daerah berpengaruh negatif dan signifikan terhadap tingkat pertumbuhan ekonomi sebesar 0.440372 dengan probabilitas sebesar 0.0082 . Artinya apabila pajak daerah menurun sebesar $1 \%$ maka akan meningkatkan tingkat pertumbuhan ekonomi sebesar $0.440372 \%$. Hal tersebut menunjukkan bahwa apabila pajak daerah mengalami peningkatan maka 
akan menurunkan tingkat pertumbuhan ekonomi di Provinsi Nusa Tenggara Barat.

Jika dilihat dari hasil bahwa pajak daerah berpengaruh negatif dan signifikan terhadap tingkat pertumbuhan ekonomi, hal ini disebabkan karena pemerintah daerah tidak digunakan untuk pembangunan daerah yang dapat memberikan efek multiplier tapi pajak daerah daerah yang di dapat digunakan lebih banyak kepada hal yang konsumtif seperti peningkatan subsidi, gaji pegawai atau belanja pegawai dan menggunakan ke event budaya daerah. Diharapkan untuk selanjutnya pemerintah lebih teapat sasarn dalam menggunakan pajak daerah agar mampu meningkatkan pemerataan pembangunan dan pertumbuhan ekonomi.

\section{Pengaruh jumlah Penduduk}

Berdasarkan hasil analisis regresi linier berganda data panel dengan model fixed effect, variabel jumlah penduduk berpengaruh negatif dan signifikan terhadap tingkat pertumbuhan ekonomi sebesar 7.816775 dengan probabilitas sebesar 0.0000. Artinya apabila jumlah penduduk menurun sebesar $1 \%$ maka akan menurunkan tingkat pertumbuhan ekonomi sebesar $7.816775 \%$. Hal tersebut menunjukkan bahwa apabila jumlah penduduk mengalami peningkatan maka akan menurunkan tingkat pertumbuhan ekonomi di Provinsi Nusa Tenggara Barat.

Jika dilihat dari hasil di atas bahwa peningkatan jumlah penduduk dapat menurunkan produktivitas karena adanya efek diminishing returns. Apabila jumlah penduduk terus meningkat melebihi titik maksimum dan tingkat produktivitas penduduk rendah, maka jumlah penduduk akan berdampak negatif atau menyebabkan pertumbuhan ekonomi menurun. Hal ini sesuai dengan pendapat Carla, 2002 suatu negara dikatakan menghadapi masalah kelebihan penduduk apabila jumlah penduduk jauh lebih besar bila dibandigkan dengan faktor-faktor produksi yang tersedia. Akibatnya produksi marginal penduduk rendah. Dengan demikian, penduduk yang berlebihan akan menimbulkan kemerosotan kemakmuran masyarakat.

\section{KESIMPULAN}

Berdasarkan hasil penelitian yang telah diolah dan dianalisis mengenai "Analisis Pengaruh Desentralisasi Fiskal Terhadap Pertumbuhan Ekonomi Di Provinsi Nusa Tenggara Barat Tahun 2011-2017" dengan model regresi linier berganda (data panel) dengan model fixed effect, adapun kesimpulan dalam penelitian ini yaitu dana alokasi umum, pajak daerah, dan pertumbuhan penduduk secara bersama-sama (simultan) dengan Uji-F berpengaruh signifikan terhadap pertumbuhan ekonomi di Provinsi Nusa Tenggara Barat. Dengan nilai Nilai F hitung 56.55709 > F tabel 3.133762 dan nilai probabilitasnya 0.0000 .

Secara parsial dengan Uji-T maka diperoleh kesimpulan yaitu dana alokasi umum berpengaruh positif signifikan, sedangkan untuk pajak daerah berpengaruh negatif signifikan dan untuk pertumbuhan penduduk 
berpengaruh positif signifikan terhadap pertumbuhan ekonomi di Provinsi Nusa Tenggara Barat. Dalam Uji-t masing-masing variabel dana alokasi umum, pajak daerah, dan pertumbuhan penduduk berpengaruh terhadap pertumbuhan ekonomi di Provinsi Nusa Tenggara Barat, dengan T-statistik yang terbesar pada variabel dana alokasi umum sebesar 8.662815. Koefisien determinasi R-squared sebesar 0.922521 hal ini menunjukkan bahwa kemampuan variabel bebas (dana alokasi umum, pajak daerah, dan pertumbuhan penduduk) dalam menjelaskan variabel terikat (pertumbuhan ekonomi) $92 \%$ (persen). Sedangkan sisanya sebesar $8 \%$ (persen) dijelaskan oleh variabel lain.

\section{DAFTAR PUSTAKA}

Adi, P. H. (2005). Dampak Desentralisasi Fiskal Terhadap Pertumbuhan Ekonomi (Studi pada Kabupaten dan Kota se Jawa-Bali), (Mardiasmo 2002), 1-20.

Anonymous, 2016. Modul Ekonometrika Dengan Software Eviews 6. Malang: Laboratorium IESP UMM.

Anita, Mohammad, S., \& Hamzah, A. (2014). Pengaruh Desentralisasi Fiskal Terhadap Pertumbuhan Ekonomi Di Provinsi Aceh, 2(3), 21-29.

Badan Pusat Statistik (BPS), Nusa Tenggara Barat Dalam Angka 2011 2018.

Brodjonegoro, B. (2001). Indonesian Intergovernmental Transfer in Decentralization Era:The Case of General Allocation Fund. The International Symposium on Intergovernmental Transfers in Asian Countries: Issues and Practices, 1-34.

Ebel, R. D., \& Yilmaz, S. (2002). Concept Of Fiscal Decentralization And Worldwide Overview, 64.

Ebel, R. D., \& Yilmaz, S. (2002b). On the Measurement and Impact of Fiscal Decentralization, (March).

Erlangga A. Landiyanto. (2005). Kinerja Keuangan Daerah dan Strategi Pembangunan Kota di Era Otonomi Daerah ( Studi Kasus Kota Surabaya). Surabaya: Universitas Airlangga Surabaya.

Mahi, R. (2002). Desentralisasi Fiskal dan Otonomi Daerah. Jakarta.

Mangkoesoebroto, G. (2001). Ekonomi Publik (Edisi-111). Yogyakarta: BPFE.

Muluk, M. R. K. (2010). Peta Konsep Desentralisasi dan Pemerintahan Daerah. Surabaya: ITS Press.

Nurcholis, H. (2005). Teori dan Praktek Pemerintahan dan Otonomi Daerah. Jakarta: Grasindo.

Poli, Carla, 2002 "Pengantar Ilmu Ekonomi Buku Panduan Mahasiswa" Penerbit PT Prenhallindo, Jakarta. 
Pose, A. R., Pike, A., John, T., Torrisi, G., \& Tselios, V. (2012). In search of the 'economic dividend' of devolution: spatial disparities, spatial economic policy, and decentralisation in the UK, 30, 10-29. https://doi.org/10.1068/c10214r

Saputra, B. (2012). Pengaruh Dsentralisasi Fiskal Terhadap Pertumbuhan Ekonomi dan Kesejahteraan Masyarakat, 16, 185-199.

Saragih, J. P. (2016). The fiscal capacity of the seven new provinces and its implications. JEJAK Journal of Economics and Policy, 9(2), 180-199.

Sasana, H. (2009). Peran Desentralisasi Fiskal Terhadap Kinerja Ekonomi Di Kabupaten/Kota Provinsi Jawa Tengah, 10(1).

Simanjuntak, R. A. (2005). Hubungan Keuangan Pusat dan Daerah Dalam Pasang Surut Otonomi Daerah: Sketsa Perjalanan 100 Tahun Robert. (A. Ganggang, Ed.). Jakarta: Yayasan Tifa.

Situngkir, F., Sirojuzilam, Erlina, \& Suriadi, A. (2014). Pengaruh Desentralisasi Fiskal Terhadap Pertumbuhan Ekonomi Di Provinsi Sumatera Utara. Jurnal Ekonom, 17, 125-137.

Slinko, I. (2002). The Impact of Fiscal Decentralization on the Budget Revenue Inequality among Municipalities and Growth of Russian regions.

Soeratno, \& Lincoln, A. (2003). Metodologi Penelitian Untuk Ekonomi. (AMP, Ed.) (UPP). Jakarta: UKPN.

Sugiyono. (2011). Metode Penelitian Kuantitatif, Kualitatif dan R\&D (Afabeta). Bandung.

Sukirno, S. (2004). Pengantar Teori Makroekonomi. Jakarta: PT. Raja Grafindo Persada.

Sukirno, S. (2008). Teori Pengantar Ekonomi Makro (Edisi 3). Jakarta: PT. Raja Grafindo Persada.

Sukirno, S. (2010). Pengantar Teori Ekonomi Makro. Jakarta: PT. Raja Grafindo Persada.

Suparmoko, M. (2002). Ekonomi Publik Untuk Keuangan dan Pembangunan Daerah (Edisi Pert). Yogyakarta.

Tarigan, R. (2004). Perencanaan Pembangunan Wilayah. Jakarata: PT Bumi Aksara.

Todaro, M. P. (2004). Pembangunan Ekonomi di Dunia (Edisi Kede). Jakarta: Erlangga.

Todaro, M. P., \& Smith, S. C. (2003). Pembangunan Ekonomi di Dunia Ketiga (Edisi Kede). Jakar: Erlangga.

Vazquez, J. M., \& Mcnab, R. M. (2001). Fiscal Decentralization and Economic Growth, (January).

Woller, G. M., \& Phillips, K. (2013). The Journal of Fiscal decentralisation and IDC economic growth: An empirical investigation, (April 2013), 37-41. 